Original articles

J. Perinat. Med. $12(1984) 115$

\title{
Heart rate variability and electrocardiogram changes in the fetal lamb during hypoxia and beta-adrenoceptor stimulation
}

\author{
H. Lilja, K. Karlsson, I. Kjellmer*, K. Lindecrantz**, T. Olsson**, \\ K. G. Rosen*
}

Department of Obstetrics and Gynecology, Sahlgren's Hospital

* Department of Pediatrics I, East Hospital, University of Göteborg

** Research Laboratory of Medical Electronics, Chalmers University of Technology, Göteborg, Sweden

\section{Introduction}

Alterations of fetal heart rate (FHR) and/or heart rate variability (FHRV) have been regarded as common signs of asphyxia, first discussed by HON and LEE [10], who noticed decreased FHRV in dying fetuses. The correlation between decreased FHRV and fetal acidosis has thereafter been established in several clinical studies [21]. The pattern of increased variability was described by HAMMACHER et al. [9], who suggested that "saltatory pattern" could be an initial sign of stress. When the first experimental results on FHRV under induced hypoxia were presented by DALTON et al. [3], an increased variability during the early phases of hypoxia was observed. The results were corroborated by STÅNGE et al. [27]. Both groups also noticed, in single animals, that decreasing FHRV again were seen in connection with severe hypoxemia.

Waveform changes in the ST segment of the fetal electrocardiogram (FECG) constitute another sensitive parameter of hypoxic stress, where the dominant reaction is a progressive increase in the $T$ wave amplitude, and where the changes can be quantified as the T/QRS ratio [7]. In the fetal lamb the FECG alterations have been correlated to the depletion of myocardial glycogen stores, thus reflecting anaerobic myocardial glycolysis. Similar FECG changes with high $T$ waves can be elicited by isoprenaline, indicating that the changes could

\section{Curriculum vitae}

HÅKAN LILJA was born in 1944, studied in Göteborg and received his $M D$ degree there in 1973. Since 1976 he is working in the Department of Obstetrics and Gynecology, Sahlgren's Hospital, Göteborg and since 1977 he has been a member of the Perinatal Group, Department of Physiology, University of Göteborg. Main field of research interest: Clinical and fetal lamb studies concerning perinatal asphyxia.

be mediated by a stimulation of the beta-adrenoceptors in the fetal heart.

Even though several studies have confirmed that changes in FHRV and FECG are signs of asphyxia, the etiologic mechanisms behind the changes in FHRV are not fully understood.

The aim of the present study was to explore whether the initial increase in FHRV seen during hypoxemia was mediated via the beta-adrenoceptors, initiated by catecholamine release. We also wanted to compare the pattern of reaction of FHRV and of FECG in response to periods of induced hypoxia. 


\section{Material and methods}

The experiments were conducted on 22 ewes of mixed breed with 26 fetuses. Their gestational age ranged from 117 to 147 days (term 145-150 days). The gestation was estimated from fetal weight and crown-rump length using standard curves [16].

\subsection{Preparation}

Food was restricted 24 hours prior to the experiment, water provided ad libitum. The anesthesia was induced with pentothal $(5 \mathrm{mg} / \mathrm{kg})$ and was maintained with chloralose $(35 \mathrm{mg} / \mathrm{kg})$. To avoid hypoglycemia,. a slow, continuous intravenous infusion of $10 \%$ glucose solution $(50-100 \mathrm{ml} / \mathrm{hr})$ was given to the ewe throughout the whole experiment. The ewes were tracheotomized and ventilated with known gas mixtures, using an open circuit ventilator. Maternal blood pressure was recorded and blood samples were obtained via a catheter placed in the medial plantar artery of one foreleg.

The uterus was explored through a paramedian abdominal incision and stitched to the abdominal wall. The uterus was opened and the fetus delivered onto a heated small table. Care was taken not to disturb the umbilical circulation. The fetal trachea was cannulated immediately after delivery and the free end of the cannula was placed under saline solution to enable free flow of lung liquid.

Fetal arterial blood pressure and heart rate were recorded by a Statham $\mathrm{P} 23 \mathrm{AC}$ pressure transducer connected to a catheter in the right brachial artery. Arterial blood samples were taken from the same catheter. Blood gas tensions and $\mathrm{pH}$ were immediately measured on a Radiometer pHM27 using standard $\mathrm{P}_{\mathrm{aO}_{2}}$ and $\mathrm{P}_{\mathrm{aCO}_{2}}$ electrodes. Hemoglobin concentration and oxygen saturation were measured spectrophotometrically with a Radiometer OSM2. The oxygen content $\left(\mathrm{ml} \mathrm{O}_{2} / \mathrm{l}\right)$ was calculated from the saturation value and the hemoglobin concentration assuming that $1 \mathrm{~g} \mathrm{Hb}$ maximally binds $1.34 \mathrm{ml} \mathrm{O}_{2}$.

The fetal ECG was recorded as a precordial lead with lead electrodes with a diameter of $0.8 \mathrm{~cm}$, placed subcutaneously on both right legs and on the left part of the chest between the apex and the left part of the sternum. The ECG signals were recorded on a Grass polygraph 7 recorder and on a FM tape recorder (TEAC R-70A) with a bandwidth of $0-625 \mathrm{~Hz}$. The ratio between the amplitude of the $T$ wave and the QRS complex (T/QRS ratio) was used as a quantitative measure of the ST waveform changes. At each moment of fetal blood sampling, real time was noted on the ECG record and on the tape. Care was taken that the ECG signal was recorded at least two minutes prior to and two minutes after the sampling event.

The ewes were exposed to alternate periods of normoxemia and hypoxemia. The hypoxemia was induced while ventilating the ewe with gas mixtures containing $10-16 \% \mathrm{O}_{2}$ in $\mathrm{N}_{2}$. The periods of hypoxemia lasted for 10-40 minutes.

To study the influence of beta-adrenoceptor. stimulation on FHRV and ST waveform changes, in 5 fetuses the left jugular vein was cannulated and $0.044,0.076,0.143,0.22$ and $0.78 \mu \mathrm{g} / \mathrm{min}$ of isoprenaline was infused during normoxia. The dose-response effect on FHR, DI, II and T/QRS ratio was analyzed.

\subsection{Estimation of FHR variability}

As a measure of short-term and long-term variability the differential index (DI) and interval index (II) was used respectively [30]. Eighty seconds of the recorded ECG coinciding in time with each fetal blood sample were analyzed using a PDP 11/40 minicomputer. The ECG signal was sampled at a rate of 1250 samples per second giving a resolution in time of $0.8 \mathrm{msec}$. Each QRS complex was detected with a semi-automatic program using a cross-correlation algorithm. QRS complexes that by the program were signalled to be doubtful were visually examined and either rejected or approved. Hence, the resulting list of $R-R$ intervals was practically free from artefacts. From this list of $R-R$ intervals the DI and II were computed according to YEH et al. [30]:

$D I=\sqrt{\frac{\sum_{i=1}^{N-1}\left(d_{i}-\bar{d}\right)^{2}}{N-2}}$ where 
$d_{i}=\frac{t_{i}-t_{i+1}}{t_{i}+t_{i+1}} \cdot 1000$ and $\bar{d}=\frac{1}{N-1}\left(\sum_{i=1}^{N-1} d_{i}\right)$

OXYGEN CONTENT $\mathrm{mlO} \mathrm{O}_{2} / \mathrm{I}$

II $=\frac{s}{t}$ where

$$
s=\sqrt{\frac{\sum_{i=1}^{N}\left(t_{i}-\bar{t}\right)^{2}}{N-1}} \cdot 100 \text { and } \bar{t}=\frac{1}{N} \sum_{i=1}^{N} t_{i}
$$

$\mathrm{N}$ is the number of R-R intervals during the eighty seconds, and $t_{1} \ldots t_{i} \ldots t_{N}$ are the lengths of the consecutive $R-R$ intervals. To facilitate the presentation II was multiplied with a factor of 100 .

\subsection{Statistics}

In order to evaluate the compact influence of the different variables a linear regression analysis was performed using the data from 24 fetuses. To analyze the influence of increasing doses of isoprenaline on FHR, DI, II and T/QRS ratio, WILCOXON rank sum test was used. The variation of mean values is given as the standard deviation (S.D.).

\section{Results}

The analysis of FHRV is based on 163 epochs of ECG recordings with a sampling period of 80 seconds. The same epochs were used when calculating the corresponding $\mathrm{T} / \mathrm{QRS}$ ratio.

\subsection{Hypoxemia}

The effect of subjecting twelve nonacidemic fetuses $(\mathrm{pH}>7.20)$ to hypoxia for 5 to 15 minutes is visualized in Fig. 1. During this period a fall in mean oxygen content from 100 to $41 \mathrm{ml} / \mathrm{l}$ was seen. During the initial phase of hypoxemia an increase was measured both in DI from $3.1 \pm 2.5$ to $17.7 \pm 13.8$ and II from $1.08 \pm 0.65$ to $3.77 \pm 2.06$ (mean \pm S.D.).

Fig. 2 demonstrates the changes in DI and T/QRS ratio parameters recorded during hypoxemia in five nonacidemic fetuses. The FHRV response

was found to be variable with an initial increase followed by a return towards prehypoxemic values. During the initial phase $\mathrm{P}_{\mathrm{a}_{2}}$ decreased from $2.63 \pm 0.48$ to $1.52 \pm 0.23(\mathrm{kPa})$ and $\mathrm{DI}$ increased from $2.3 \pm 1.6$ to $31.2 \pm 9.0$ (mean $\pm \mathrm{SD}$ ). The later phase of the hypoxemic period $\left(\mathrm{P}_{\mathrm{aO}_{2}} 1.22 \pm 0.40\right)$ was characterized by a decrease in $\mathrm{DI}^{2}$ to $19.4 \pm 20.7$. The change in T/QRS ratio had a slower onset and was first prominent at prolonged hypoxemia with a rise from $0.23 \pm 0.18$ to $0.84 \pm 0.43$ at the end of hypoxemia. No appearent changes occurred in FHR, $\mathrm{PaCO}_{2}$ or $\mathrm{pH}$.

Both in Fig. 1 and 2 a wide variation in variability indices is obvious. This is further substantiated in Fig. 3. This figure displays the relation between FHRV expressed as DI and hypoxemia expressed as oxygen content at three different levels of $\mathrm{pH}$, signifying no, moderate and severe acidosis. During situations with oxygen content above $50 \mathrm{ml} / 1$ there is, with one exception, a low DI, 


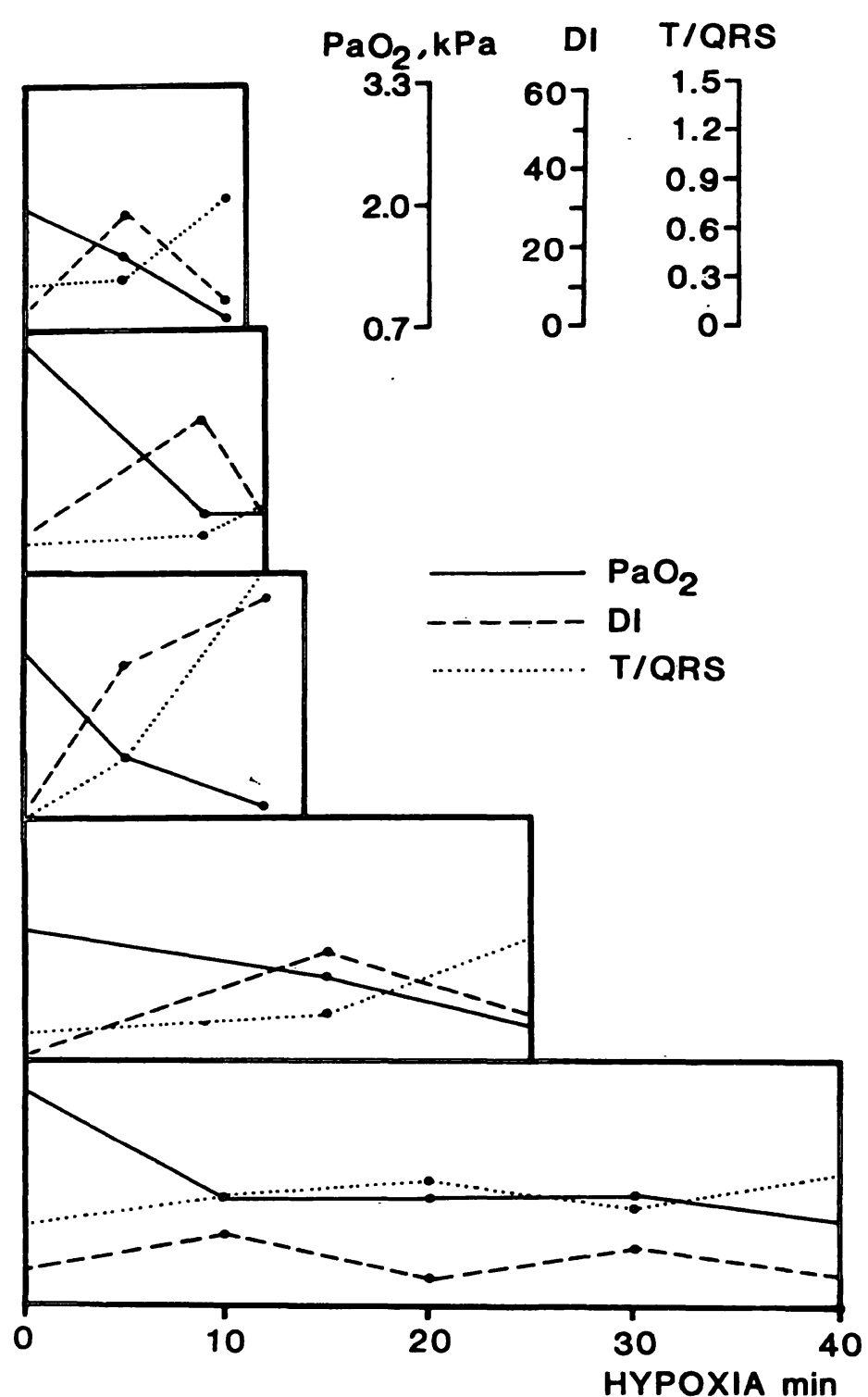

Fig. 2. The dynamic pattern of $D I$ and $T / Q R S$ ratio during hypoxia in five fetal lambs.

independent of any degree of acidosis. However, during hypoxemia (oxygen content $<50 \mathrm{ml} / \mathrm{l}$ ) most nonacidemic observations showed increased DI. With the combination of hypoxemia and acidosis, on the other hand, the observed DI was again low.

A regression analysis including all variables obtained during 99 epochs from 24 fetuses during normoxemia and hypoxemia is given in Tab. I. The matrix confirms the findings visualized in Figs. 1,2 and 3. There is a highly significant relation between $\mathrm{P}_{\mathrm{a}_{\mathrm{O}}}$ and the variability indices (DI and II), $\mathrm{n}=93^{2}$, $T=-5.34$ and $T=-4.32$ respectively. This fact, however, is not obvious in Fig. 3 where a wide variation of DI during low oxygen content is seen,

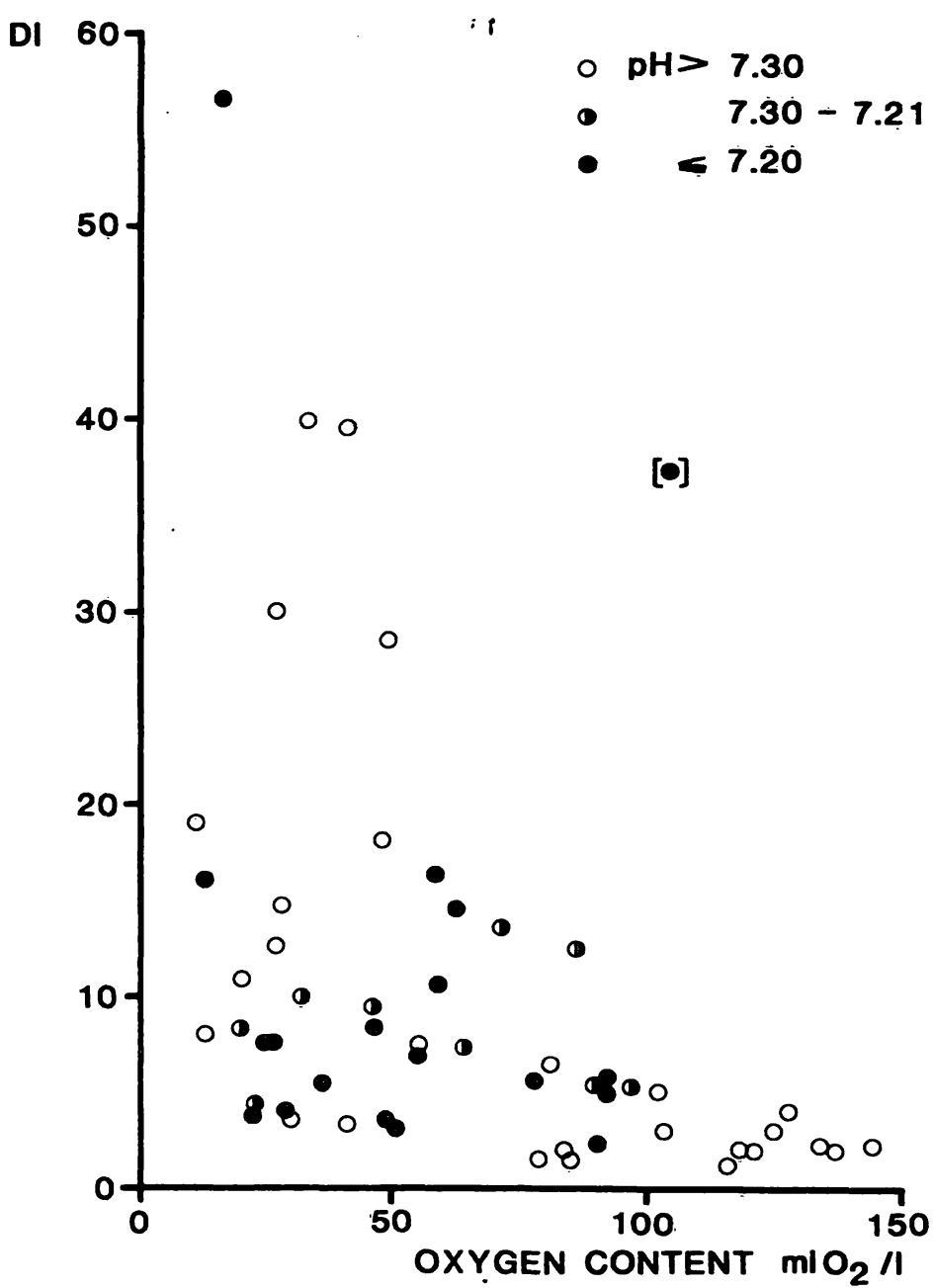

Fig. 3. The relationship between oxygen content and DI during no, slight or severe acidosis. 55 observations from 17 fetal lambs are given. The observation in brackets represents a fetus with mean arterial blood pressure $36 \mathrm{~mm} \mathrm{Hg}$ and fetal heart rate 275 beats/min.

with preferably low differential indices during acidemia. The regression analysis confirmed this observation, as no relation was found between DI and $\mathrm{pH} \quad(\mathrm{n}=93, \mathrm{~T}=-1.85)$. The long-term variability (II) reacted in a similar way as DI during hypoxemia and acidosis but generally had a weaker correlation than DI to the different tested variables. There was a strong relation between DI and II $(\mathrm{n}=93, \mathrm{~T}=15.66)$.

To elucidate whether the change in oxygen content per se influenced on DI, $\Delta$ oxygen content/min was correlated to $\Delta \mathrm{DI} / \mathrm{min}$ using consequtive observations. A strong correlation was found $(\mathrm{r}=0.81)$.

Furthermore, as also seen in Tab. I, a significant relation existed between $T / Q R S$ and $\mathrm{P}_{\mathrm{aO}_{2}},(n=99$, $T=-3.17)$, and between $T / Q R S$ and $\mathrm{pH}(n=99$, $\mathrm{T}=-2.67)$. 
Tab. I. Correlation matrix from 99 observations gained from the experiments. Asterisks indicate significant relations in the linear regression analysis.

\begin{tabular}{|c|c|c|c|c|c|c|c|c|c|}
\hline & MAP & FHR & $\mathrm{PaO}_{2}$ & $\mathrm{PaCO}_{2}$ & $\mathrm{pH}$ & $\mathrm{S}_{\mathrm{aO}_{2}}$ & DI & II & $\mathrm{T} / \mathrm{QRS}$ \\
\hline MAP & 1.00 & & & & & & & & \\
\hline FHR & $0.30^{* *}$ & 1.00 & & & & & & & \\
\hline $\mathrm{PaO}_{2}$ & -0.11 & $0.22 *$ & 1.00 & & & & & & \\
\hline $\mathrm{P}_{\mathrm{aCO}_{2}}$ & -0.07 & 0.15 & 0.12 & 1.00 & & & & & \\
\hline $\mathrm{pH}$ & 0.02 & $-0.35 * * *$ & -0.02 & $-0.72 * * *$ & 1.00 & & & & \\
\hline $\mathrm{S}_{\mathrm{aO}_{2}}$ & -0.08 & -0.03 & $0.77 * * *$ & $-0.30 * *$ & $0.36 * * *$ & 1.00 & & & \\
\hline DI & 0.12 & -0.20 & $-0.49 * * *$ & $0.21 *$ & -0.19 & $-0.56 * * *$ & 1.00 & & \\
\hline II & -0.06 & -0.19 & $-0.41 * * *$ & 0.17 & -0.10 & $-0.47 * * *$ & $0.85 * * *$ & 1.00 & \\
\hline $\mathrm{T} / \mathrm{QRS}$ & 0.19 & 0.03 & $-0.31 * *$ & $0.21 *$ & $-0.26 * *$ & $-0.40 * * *$ & $0.42 * * *$ & $0.33^{* *}$ & 1.00 \\
\hline
\end{tabular}

\subsection{Beta-adrenoceptor stimulation}

To elucidate whether the changes in DI, II, FHR and $T / Q R S$ ratio during hypoxemic stress were neuro-humoral responses, mediated via the betaadrenoceptors of the autonomic nervous system, six normoxemic, nonacidemic fetuses were given increasing doses of isoprenaline (Fig. 4). No changes in $\mathrm{PaO}_{2}, \mathrm{PaCO}_{2}$ or $\mathrm{pH}$ during the infusion

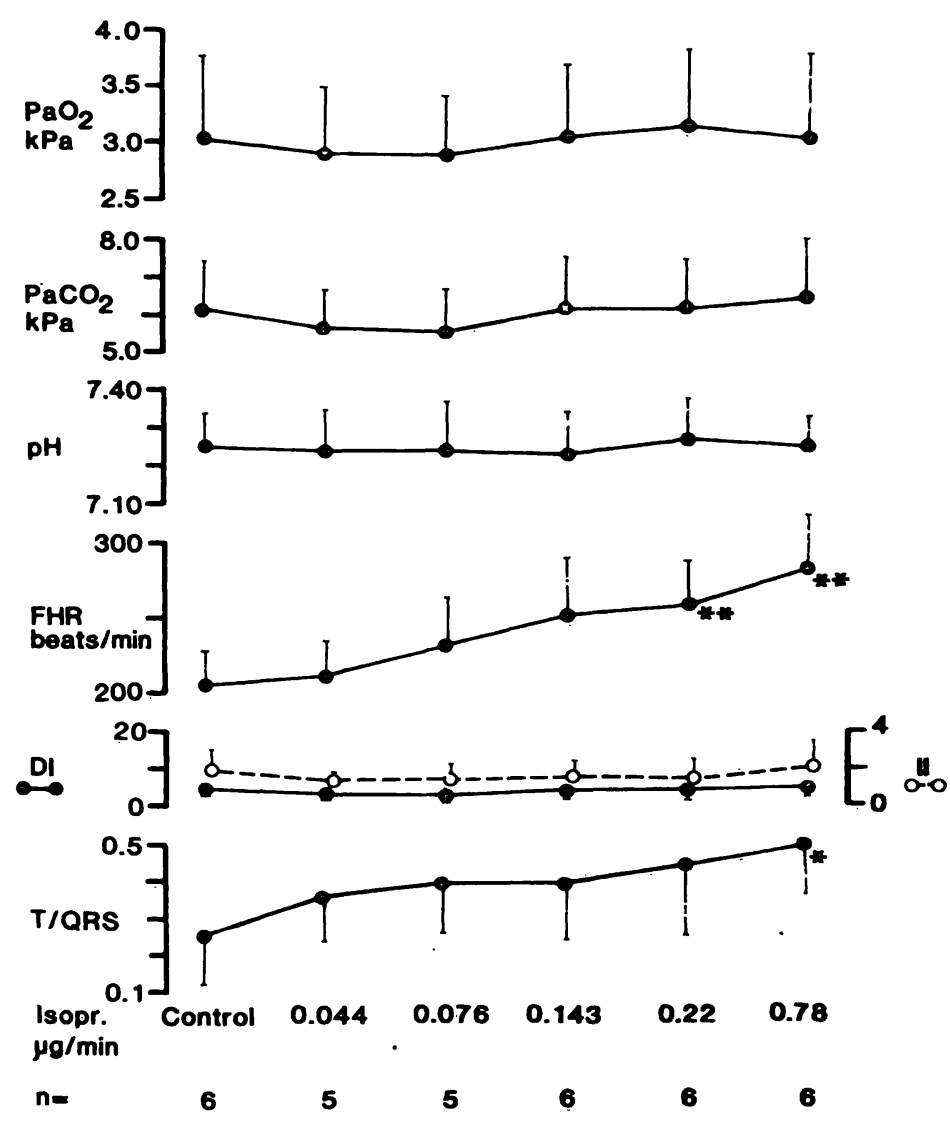

Fig. 4. The effect of isoprenaline infusion $(\mu \mathrm{g} / \mathrm{min})$ on fetal heart rate, short-term variability (DI) and T/QRS ratio. Blood gases and $\mathrm{pH}$ is visualized in top of the figure. ${ }^{*} \mathrm{p}<0.05,{ }^{* *} \mathrm{p}<0.02$. were seen. Mean FHR increased from 205 to 288 $(p<0.02)$. No changes whatsoever occurred in the corresponding DI or II due to the beta-stimulating agent.

Considering the fetal ECG waveform, increasing doses of isoprenaline resulted in increasing $T$ waves. The given doses did not result in the same degree of changes as were seen during hypoxemia and acidosis. However, when the maximum dose of isoprenaline was given $(0.78 \mu \mathrm{g} / \mathrm{min})$, a significant rise in the mean $\mathrm{T} / \mathrm{QRS}$ ratio from initial 0.27 to 0.51 was seen $(\mathrm{p}<0.05)$.

\section{Discussion}

This study was performed on the anesthetized, exteriorized fetal lamb. This might limit the applicability of the results but it does not invalidate the main results for several reasons. First, we wanted to persue our previous findings of an increase of FHRV during fetal hypoxemia obtained on the same type of preparation [27]. Second, we avoided anesthetics known to influence seriously the autonomic control of the circulatory apparatus and selected, after induction with a short acting barbiturate in a single dose, to use chloralose, claimed to have little influence on respiratory and cardiovascular reflexes [8]. Third, our fetal lamb preparation reacted closely similar to the nonanesthetized chronic fetal sheep preparation with regard to basal blood gas values [15] and to the beat-to-beat variability both during normoxemia and hypoxemia [4]. 
Heart rate variability changes are considered to reflect the balance between the sympathetic and the parasympathetic centers that control the heart rate. Here the interest was focused on the sympathetic influence as we wanted to compare the FHRV changes to ECG changes known to be elicited by beta-adrenoceptor stimulation.

In this study no rejection algorithm has been needed as we have visually examined all doubtful QRS complexes. We have thus been able to recognize and to include the true $R-R$ intervals deviating excessively from the mean $R-R$ interval length. This procedure explains why we have epochs with more variability than reported by others who have been using automatic rejection algorithm, e.g. KARINIEMI ẹt al. [17].

The strong correlation between DI and II found by us as well as others [17], does not contradict the fact that DI and II reflect different phenomena. The DI is known to be sensitive to e.g. hypoxemia, while II merely reflects the fetal arousal level. The correlation is rather a result of the short epoch length. This makes it impossible to consider biological rhythms with periods longer than the sampling epochs. As an effect of the anesthesia, both the influence from the fetal arousal level and the fetal breathing movements was partly depressed. To facilitate the presentation of II a factor 100 is used. This has not been described by neither YEH nor KARINIEMI. However, our II values are in the same order as theirs.

The length of the time period during which FHRV is analysed and the method used influences the result [4]. After studies on a simulated signal DETWILER et al. [6] suggested that an epoch length of at least five minutes was necessary to obtain good estimates of short-term variability indices. However, KARINIEMI et al. found a good correlation between one-minute and five-minute epochs for estimation of DI [18]. Long epochs are advantageous only if the indices can be assumed to be stationary throughout the epoch.

A controversial question in fetal monitoring is, to what extent the FHRV is an indicator of fetal asphyxia, and to what degree different physiological factors may influence on the variability [4]. The predominant opinion has earlier been that decreased variability is' a sign of threatening asphyxia $[9,10]$.

In this study we confirmed earlier results from this laboratory [27] showing a prompt increase in DI and II from initially low values when a nonacidemic fetus was submitted to hypoxemia (Fig. 1, Tab. I). Similar results were obtained by several groups both from the chronically instrumented lamb fetus and from primates $[4,14,25]$. Our finding of a close correlation between the change of oxygen content and the change of DI further substantiates the quantitative relation between hypoxemia and FHRV. Clinical studies have also indicated increasing variability during the early stages of hypoxia, both assessed from cardiotochographic recordings $[9,21]$ and from the combination of fetal ECG recordings and $t c \mathrm{P}_{\mathrm{O}_{2}}$ measurements $[11,29]$.

There is strong evidence that hypoxemia and asphyxia induce an increase in the concentration of catecholamines in fetal blood [2, 23]. Earlier studies from our laboratory have revealed similar changes in the FECG waveform during hypoxemia and during beta-adrenoceptor stimulation [12]. We therefore suggested that both the FECG changes and the increase of FHRV during hypoxemia were mediated via beta-adrenoceptors. In the present study, though, no changes in variability indices were seen after beta-stimulation. This could be a counteraction of the positive chronotrope effect on the fetal heart. However, during initial hypoxemia, an increase in DI but no increase in FHR were seen, which therefore makes it less plausible that the FHRV increase during hypoxemia is mediated via beta-adrenoceptors. PARDI et al. [24] and DALTON et al. [4] both found increased variability after alpha- and alpha + beta adrenoceptor stimulation, respectively. The conclusion therefore might be that these changes in DI during initial nonacidemic hypoxemia mainly are mediated via alpha- and not via betareceptor stimulation.

During prolonged hypoxemia, when additional acidosis appeared, we found a moderation of the FHRV with decreasing DI (Fig. 3). These findings are in accordance with clinical data [19]. It was suggested that loss of beat to beat variation occurs 
when hypoxemia is combined with acidosis into an asphyxia.

We only found a weak positive relation between hypercapnia and DI and to II no relation at all. DALTON did not observe any significant connection between FHRV and $\mathrm{P}_{\mathrm{CO}_{2}}$ whereas IKENOUE [14] did. As both DALTON's and IKENOUE's groups found increased fetal breathing movements (FBM) during hypercapnia and MURATA [22] found an increase in FBM after beta-and a decrease after alpha-stimulation, these data together with our results would suggest that the fetal response to respiratory acidosis is decreasing variability mediated via the beta-adrenoceptor cells.

During hypoxia FHR often rises (Tab. I). Controversy exist in the literature concerning the impact of FHR on changes in FHRV [5, 28]. This might be due to differences in statistical methods. In the present study using statistical indices of YEH [30] no correlation between FHR and DI (Tab. I) was found.

\section{Summary}

Hypoxic changes in the ST waveform of the fetal electrocardiogram (FECG), with elevated $T$ waves as the main response, have earlier been described in the fetal lamb as mediated via the beta-adrenoceptor cells, initiated by catecholamine release. A similar background to the increase in fetal heart rate variability (FHRV) during hypoxemia has been suggested. The aim of the present study was to elucidate this question and also to compare FHRV and changes in the ST waveform of the FECG as indicators of fetal distress.

Twenty-six acutely exteriorized mature lamb fetuses were submitted to periods of graded hypoxemia. Fetal blood gases were measured and oxygen content was calculated. The FHRV was analyzed by a computer program and calculated as the differential index (DI) and the interval index (II). Eighty seconds of the recorded ECG coinciding in time with each fetal blood sample were analyzed using a PDP 11/40 minicomputer. The ECG signal was sampled at a rate of 1250 samples per second giving a resolution in time of $0.8 \mathrm{msec}$. Each QRS complex was detected with a semi-automatic program using a cross-correlation algorithm. QRS complexes that by the program were signalled to be doubtful were visually examined and either rejected or approved. Hence, the resulting list of R-R intervals was practically free from artefacts. From this list of $R-R$ intervals the DI and II were computed according to YEH et al. [30]. Hypoxemia resulted in initially strongly increased DI from $3.1 \pm 2.5$ to $17.7 \pm 13.8(\mathrm{p}<0.001)$ and in II from $1.88 \pm 0.65$ to $3.77 \pm 2.06(\mathrm{p}<0.001)$ (Fig. 1). Obviously the change in oxygen content per se was strongly associated with the variability indices, as we
Clinically several studies have been performed on beta-stimulant drugs during preterm labour without evidence of any influence on heart rate variability of the healthy fetus [1].

Finally, earlier studies from our group have revealed ST waveform changes with increasing $\mathrm{T}$ wave amplitude related to anaerobic glycogenolysis in the myocardium, an effect of betaadrenoceptor stimulation $[12,13]$, a pattern otherwise seen during fetal asphyxia [7]. A strong correlation between $T$ wave amplitude and circulating adrenaline has also been found [26]. Although there was a strong relation between decreasing $P_{\mathrm{aO}_{2}}$ and increasing $\mathrm{T} / \mathrm{QRS}$ ratio (Tab. I), it is obvious that FHRV, if not influenced by other factors, is an early and sensitive detector of fetal hypoxemia, whereas significant changes in FECG appears later in the hypoxemic period and also correlate to metabolic changes. This could make it usable in the field of fetal monitoring [20].

found a strong correlation between $\Delta$ oxygen content $/ \mathrm{min}$ and $\Delta \mathrm{DI} / \mathrm{min}(\mathrm{r}=0.81)$. In five fetuses the effect of prolonged hypoxemia on DI was studied (Fig. 2). After the initial rise from $1.6 \pm 1.1$ to $31.2 \pm 9.0(\mathrm{p}<0.02)$ DI decreased to $19.4 \pm 20.7$. A regression analysis showed a strong connection between DI and $\mathrm{PaO}_{2}, \quad(n=93$, $T=-5.34)$, whether there was no relation between DI and $\mathrm{pH}(\mathrm{T}=-1.85)$.

There is strong evidence that hypoxemia and asphyxia induce an increase in the concentration of catecholamines in fetal blood [2, 23]. Earlier studies from our laboratory have revealed similar changes in the FECG waveform during hypoxemia and during beta-adrenoceptor stimulation [12]. We therefore suggested that both the FECG changes and the increase of FHRV during hypoxemia were mediated via beta-adrenoceptors. However, during isoprenaline infusion no change in DI or II was seen whereas there was a significant rise in $T / Q R S$ ratio from 0.30 to 0.51 ( $p<0.05$, Fig. 4 ).

The length of the time period during which FHRV is analysed influences the result [4]. An epoch length of at least five minutes has been suggested to obtain good estimates of short-term variability indices [6]. However, long epochs are advantageous only of the indices can be assumed to be stationary throughout the epoch. As we have visually examined all doubtful QRS complexes no rejection algorithm has been needed. We have thus been able to recognize and to include the true $R-R$ intervals deviating excessively from the mean $R-R$ interval length. This procedure explains why we have epochs with more variability than reported by others who have been using 
automatic rejection algorithm, e.g. KARINIEMI et al. [17]. We found a close relation between short- and long-term variability (DI, II). This might be due to the short sampling epochs which makes it impossible to consider biological rhythms with periods longer than the sampling epochs. Also the arousal level was partly suppressed by the anesthesia. However, this close relation was also found by others [17].

The ST waveform changes during hypoxemia had a slower onset than the FHRV changes but were progressive during prolonged hypoxemia, with an increase from the prehypoxemic value $0.23 \pm 0.18$ to $0.84 \pm 0.43$ $(p<0.02)$ at the end of the hypoxemic period (Fig. 2). A significant relation was found between $T / Q R S$ and $\mathrm{PaO}_{2}$,
( $\mathrm{n}=99, \mathrm{~T}=-3.17$ ), and' 'also between $\mathrm{T} / \mathrm{QRS}$ and $\mathrm{pH}(\mathrm{T}=-2.67)$ (Tab. I).

Considering the given facts, the increase in DI during hypoxemia appears not to be meadiated via the betaadrenoceptors, especially as it is not accompanied by a positive chronotropic effect on the fetal heart. It is suggested that the increased FHRV instead could be an effect of alpha-receptor stimulation. Estimation of FHRV appears, if not influenced by other factors, to enable an early and sensitive detection of fetal hypoxemia, whereas the method is difficult to interpret during acidosis. Significant changes in the FECG is seen during prolonged hypoxemia and also correlate to metabolic disturbances.

Keywords: Adrenergic adrenoceptor agonists, catecholamines, fetal anoxia, fetal electrocardiogram, fetal heart, fetal heart rate, fetal heart rate variability.

\section{Zusammenfassung}

Veränderungen der Herzfrequenzvariabilität und des Elektrokardiogramms beim Schaffeten unter Hypoxie und Stimulation der $\beta$-adrenergen Rezeptoren

Schon früher wurden beim Schaffeten ST-Streckenveränderungen mit angehobener $T$-Welle im fetalen Elektrokardiogramm (FECG) in Folge einer Hypoxie beschrieben. Diese Effekte sollten über eine Katecholaminausschüttung, die $\beta$-adrenerge Rezeptoren stimuliert, ausgelöst werden. Ähnlich versuchte man, sich auch die Zunahme der fetalen Herzfrequenzvariabilität (FHRV) während einer Hypoxämie zu erklären. Ziel der vorliegenden Arbeit war die genauere Untersuchung dieser Fragestellung und der Vergleich zwischen FHRV und Veränderungen der ST-Strecke im. FECG als Indikatoren für ein fetales Distress.

26 freipräparierte, reife Schaffeten wurden für bestimmte Perioden einer abgestufen Hypoxämie ausgesetzt. Den $\mathrm{O}_{2}$-Gehalt berechneten wir aus den fetalen Blutgasen. Die FHRV wurde über ein Computerprogramm analysiert und mit dem Differentialindex (DI) sowie dem Intervallindex (II) beschrieben. Es wurden jeweils die 80 Sekunden des aufgezeichneten ECGs, die mit der fetalen Blutentnahme zusammenfielen, mit einem PDP 11/40-Minicomputer ausgewertet. Das ECG wurde mit einer Rate von 1250 Werten pro Sekunde abgetastet, was einer zeitlichen Auflösung von $0,8 \mathrm{msec}$ entspricht. Jeder QRS-Komplex wurde mit einem semi-automatischen Programm unter Benutzung eines Kreuzkorrelations-Algorithmus erfaßt. QRS-Komplexe, die auf diese Weise als zweifelhaft ausgewiesen wurden, überprüften wir visuell und bezogen sie daraufhin in unsere Auswertung ein oder verwarfen sie, so daß die ausgewerteten R-R-Intervalle praktisch frei von Artefakten waren. Wir berechneten den DI und II nach YEH et al. [30].

Eine Hypoxämie löste zu Beginn einen starken Anstieg des DI von $3,1 \pm 2,5$ auf $17,7 \pm 13,8(p<0,001)$ und des II von $1,88 \pm 0,65$ auf $3,77 \pm 2,06 \quad(p<0,001)$ aus (Fig. 1). Es war ganz offensichtlich, daß Veränderungen des $\mathrm{O}_{2}$-Gehalts assoziiert sind mit Veränderungen der Variabilitätsindices; $\Delta \mathrm{O}_{2}$-Gehalt $/ \mathrm{min}$ und $\Delta \mathrm{DI} / \mathrm{min}$ waren streng miteinander korreliert $(r=0,81)$. Bei 5 Feten wurde der Einfluß einer länger anhaltenden Hypoxämie auf den DI untersucht (Fig. 2). Nach dem initialen Anstieg von $1,6 \pm 1,1$ auf $31,2 \pm 9,0(p<0,02)$ sank der DI auf $19,4 \pm 20,7$. Mit der Regressionsanalyse ließ sich eine strenge Beziehung zwischen dem DI und dem $\mathrm{P}_{\mathrm{aO}}$ nachweisen $(n=93, T=-5,34)$, jedoch bestand kein Zusammenhang zwischen dem DI und dem $\mathrm{pH}(\mathrm{T}=-1,85)$.

Ohne Zweifel löst eine Hypoxie und Asphyxie einen Anstieg der Katecholamine im fetalen Blut aus [2, 23]. Bei früheren Experimenten in unserem Labor konnten wir zeigen, daß unter Hypoxämie und unter Stimulation $\beta$-adrenerger Rezeptoren ähnliche FECG-Muster entstehen [12]. Daraus haben wir geschlossen, daß sowohl FECGVeränderungen wie auch der Anstieg der FHRV während einer Hypoxie über die Stimulation der $\beta$-adrenergen Rezeptoren ausgelöst wird. Auf der anderen Seite konnte unter Isoprenalininfusion keine Veränderung des DI oder II beobachtet werden, während das T/QRS-Verhältnis von 0,30 auf 0,51 anstieg; ( $p<0,05$, Fig. 4 ).

Bei der Analyse der FHRV beeinflußt die Auswertungsdauer das Ergebnis [4]. Um die Kurzzeitvariabilität richtig einschätzen zu können, wird eine Beobachtungsperiode von mindestens 5 Minuten gefordert [6]. Darüber hinaus muß man von der Annahme ausgehen, daß sich die Indizes auch außerhalb der Beobachtungsphasen stationär verhalten. $\mathrm{Da}$ alle zweifelhaften $\mathrm{QRS}-\mathrm{Komplexe}$ visuell überprüft wurden, war eine Validitätsberechnung nicht notwendig. Auf diese Weise konnten wir auch R-R-Intervalle erkennen und berücksichtigen, die exzessiv von der durchschnittlichen R-R-Intervallänge abwichen. Dieses Vorgehen erklärt, warum wir Perioden mit größerer Variabilität berücksichtigen konnten als Untersucher, die eine automatische Überprüfung der Validität einsetzten wie KARINIEMI et al. [17]. Wir konnten eine enge Beziehung zwischen Langzeit- und Kurzzeitvariabilität (DI, II) konstatieren. Dies könnte auf die kurze Beobachtungsdauer zurückzuführen sein, wodurch biologische Veränderungen außerhalb der Beobachtungsphase nicht berücksichtigt werden. Auch war das Reaktionsvermögen der Feten teilweise durch die Anästhesie eingeschränkt. Die enge Beziehung zwischen DI und II wurde jedoch auch von anderen Autoren beobachtet [17].

ST-Streckenveränderungen während einer Hypoxämie setzen langsamer ein als Veränderungen der FHRV, zeigen jedoch ein progressives Verhalten während einer 
länger andauernden Hypoxämie. Bei prähypoxämischen Zuständen berechneten wir Werte von $0,23 \pm 0,18$, am Ende hypoxämischer Perioden $0,84 \pm 0,43$ ( $p<0,02$; Fig. 2). Die Beziehung zwischen $T / Q R S$ und $\mathrm{P}_{\mathrm{aO}}$ war signifikant ( $\mathrm{n}=99, \mathrm{~T}=-3,17)$, cbenso der Koeffizient zwischen $\mathrm{T} / \mathrm{QRS}$ und $\mathrm{pH}(\mathrm{T}=-2,67)$ (Tab.1).

Unter Berücksichtigung der vorliegenden Ergebnisse scheint die Zunahme des DI unter Hypoxämie nicht über die $\beta$-adrenergen Rezeptoren vermittelt zu sein, insbesondere da sie nicht mit einem positiven chrono- tropen Effekt auf das fetale Herz einhergeht. Wir glauben stattdessen, daß die erhöhte FHRV Folge einer Stimulation der $\alpha$-Rezeptoren ist. Die Auswertung der FHRV scheint, wenn sie nicht durch andere Faktoren beeinflußt wird, eine früh einsetzbare, empfindliche Methode zur Erkennung einer fetalen Hypoxämie. Bei azidotischen Zuständen ist die Interpretation schwierig. Im FECG können bei prolongierten Hypoxämien signifikante Veränderungen beobachtet werden, die ebenfalls mit metabolischen Störungen korrelieren.

Schlüsselwörter: Agonisten der $\beta$-adrenergen Rezeptoren, fetale Anoxie, fetales Elektrokardiogramm, fetales Herz, fetale Herzfrequenz, fetale Herzfrequenzvariabilität, Katecholamine.

\section{Résumé}

Instabilité du rythme cardiaque et modifications électrocardiographiques chez le fœtus d'agneau lors $d$ 'hypoxie et de stimulation béta-adrénergique.

Les modifications hypoxiques du segment ST de l'électrocardiogramme fœtal (ECGF), avec comme perturbation principale une élévation de l'onde $\mathrm{T}$, ont été antérieurment décrites chez le fœtus d'agneau, elles sont déclenchées par la libération de catécholamines, par l'intermćdiaire des cellules béta-réceptrices. On a suggéré un schéma similaire pour expliquer l'augmentation de l'instabilité du rythme cardiaque fœtal (IRCF) en cours d'hypoxémie. Le but de cette étude a été d'élucider cette question et également de comparer l'IRCF et les modifications du segment ST de l'ECGF comme indicateurs de souffrance fœtale. On a soumis vingt-six fœtus d'agneaux matures extériorisés de façon aigüe, à des périodes d hypoxémie progressive. On a mesuré les gaz du sang fœtal et la teneur en oxygène a été calculée. L'IRCF a été analy sée à l'aide d'un ordinateur et calculée comme index différentiel (ID) et comme index d'intervalle (II). On a analy sé à l'aide d'un mini-ordinateur PDP $11 / 40$ les quatrevingt secondes d'ECG enregistré correspondantes à chaque échantillon de sang fœtal. Le signal ECG a été enregistré à une fréquence de 1250 par seconde ce qui donne une résolution temporelle de $0,8 \mathrm{msec}$. Chaque complexe QRS a été détecté par un programme semi-automatique utilisant un algorithme de corrélation croisée. Les complexes QRS signalés douteux par le programme ont été examinés visuellement et ont été soit éliminés soit acceptés. De telle sorte que la séquence résultante des intervalles $R-R$ a été pratiquement sans artéfact. Les ID et les II ont été calculés par ordinateur à partir de cette séquence d'intervalles R-R comme YEH et coll. [30].

L'hypoxémie entraîne une forte augmentation initiale de I'ID, de $3,1 \pm 2,5$ à $17,7 \pm 13,8(p<0,001)$ et de l'Il de $1,88 \pm 0,65^{\text {à }} 3,77 \pm 2,06^{\circ}$ ( $p<0,001$ ) (Fig. 1). Les modifications de la teneur en oxygène en soi sont manifestement associées fortement avec les indices d'instabilité; c'est ainsi que nous avons trouvé une corrélation forte entre le $\Delta$ teneur en exygène/min et le $\Delta \mathrm{ID} / \mathrm{min}(\mathrm{r}=0,81)$. On a étudié chez cinq fœtus l'effet d'une hypoxémie prolongée sur l'ID (Fig. 2). Après l'élévation initiale de $1,6 \pm 1,1$ à $31,2 \pm 9,0$ (p<0,02), l'ID s'abaisse à $19,4 \pm 2,7$. Une analyse par régression montre une liaison forte entre l'ID et la $\mathrm{PaO}_{2}(n=93$, $T=-5,34)$, bien qu'il $n$ 'y ait pas de relation entre l'ID et le $\mathrm{pH}(\mathrm{T}=-1,85)$.
Il existe des preuves solides du fait que l'hypoxémie et l'asphyxie provoquent une augmentation de la concentration sanguine fœtale en catécholamines [2, 23]. Des études antérieures dans notre laboratoire ont révélé des modifications similaires de l'ECGF au cours d'hypoxémie et de stimulation béta-adrénergique [11]. Ccpendant, on n'a pas observé de modification de l'ID ni de l'II lors de perfusions d'isoprénaline, alors qu'augmente de façon significative le rapport $\mathrm{T} / \mathrm{QRS}$ de 0,30 à $0,51(\mathrm{p}<0,05)$ (Fig. 4).

La longueur de l'échantillon pendant laquelle on analyse l'IRCF influence les résultats [4]. On a suggéré qu'un échantillon d'au moins 5 minutes est nécessaire pour obtenir une bonne estimation des indices d'instabilité à court terme [6]. Néanmoins, des échantillons longs ne sont avantageux que si l'on est assuré que les indices seront stationnaires pendant toute la durée de la période. Comme nous avons examiné visuellement tous les complexes QRS douteux, il n'a pas été besoin d'algorithme de rejet. Nous avons ainsi ćté capable de reconnaitre et d'inclure les intervalles $R-R$ vrais s'écartant excessivement de la longueur moyenne des intervalles $R-R$. Cette procédure explique pourquoi nous avons des périodes avec une instabilité plus grande que celle rapportée par d'autres qui ont utilisé un algorithme de rejet automatique, par ex. KARINIEMI et coll. [17]. Nous avons trouvé une relation étroite entre l'instabilité à court e à long terme (ID, II). Cela pourrait être secondaire au fait que les périodes courtes d'échantillonage rendent impossible de considérer les rythmes biologiques à périodicité plus longue que les échantillons. Egalement les taux d'éveils ont été en partie supprimés par l'anesthésie. Cependant, cette relation étroite a également été trouvée par d'autres [17].

Les modifications du segment ST en cours d hypoxémie ont un début plus lent que les modifications de l'IRCF mais sont progressives pendant une hypoxémie prolongée, avec une augmentation depuis les valeurs préhypoxémiques de $0,23 \pm 0,18$ à $0,84 \pm 0,43(p<0,02)$ à la fín de la période hypoxémique (Fig. 2). On a trouvé une relation significative entre le rapport $T / Q R S$ et la $\mathrm{PaO}_{\mathrm{aO}_{2}}$, $(\mathrm{n}=99, \mathrm{~T}=-3,17)$ et également entre $T / Q R S$ et le $\mathrm{pH}(\mathrm{T}=-2,67)$ (Tab. I).

Si l'on considère les faits exposés, l'augmentation de l'ID en cours d'hypoxémie n'apparaît pas être médiatée par l'intermédiaire des récepteurs béta, tout particulièrement car elle ne s'accompagne pas d'un effet chronotrope positif sur le cœur fœtal. A l'inverse, il est suggéré que 
l'augmentation de l'IRCF purrait être un effet de la stimulation des récepteurs alpha. L'estimation de l'IRCF, si elle n'est pas influencée par d'autres facteurs, apparaît comme capable de détecter précocement et de façon sensible l'hypoxémie fatale, tandis que la méthode est difficile à interpréter loŕs d'acidose. On observe des modifications significatives de l'ECGF pendant l'hypoxémie prolongée, corrélées égalęment avec les perturbations métaboliques.

Mots-clés: Agonistes des récepteurs adrenergiques, anoxie fœtale, catécholamines, cœur fœtal, électrocardiogramme fœtal, instabilité du rythme cardiaque fœtal, rythme cardiaque fœtal.

Acknowledgement: This research was supported by grants from the Swedish Medical Research Council (2591), the Faculty of Medicine, University of Göteborg, the Göteborg Medical Society and the "Expressen" Prenatal Research Foundation.

\section{Bibliography}

[1] CHEZ, R. A.: Preterm labor: The use of betamimetics. In: Preterm Labor, ELDER, M. G., C. H. HENDRICKS, (eds.) Butterworths (Butterworths International Medical Reviews: Obstetrics and Gynecology 1), p. 124, London, 1981

[2] COMLINE, R.S., M. SILVER: Development of activity in the adrenal medulla of the foetus and new-born animal. Brit. Med. Bull. 22 (1966) 16

[3] DALTON, K.J., G.S. DAWES, J. E. PATRICK: Foetal heart rate variation in sheep. J. Physiol. (Lond.) 256 (1976) $37 \mathrm{P}$

[4] DAlton, K. J., G. S. DAWES, J. E. PATRICK: Diurnal, respiratory, and other rythms of fetal heart rate in lambs. Am. J. Obstet. Gynecol. 127 (1977) 414

[5] DE HAAN, J.: De snelle variaties in het foetale hart frequentiepatroon. Dissertation. Amsterdam, 1971

[6] DETWILER, J. S., W. JARISCH, S. N. CARITIS: Statistical fluctuations in the heart rate variability indices. Am. J. Obstet. Gynecol. 136 (1980) 243

[7] GREENE, K. R., G. S. DAWES, H. LILJA, K. G. ROSEN: Changes in the ST waveform of the fetal lamb electrocardiogram with hypoxemia. Am.J. Obstet. Gynecol. 144 (1982) 950

[8] GREISHEIMER, E. M.: Circulatory effect of anesthetics. In: Handbook of Physiology, Section 2, Circulation Vol III, HAMILTON, W. F., P. DOW (eds.). American Physiological Society, Washington D.C. p. 2477 (1965)

[9] HAMMACHER, K., K. A. HÜTER, J. BOKELMANN, P. H. WERNERS: Foetal heart frequency and perinatal condition of the foetus and newborn. Gynaecologia (Basel) 166 (1968) 349

[10] HON, E. H., S. T. LEE: Electronic evaluation of the fetal heart rate. VIII. Patterns preceeding fetal death, further observations. Am. J. Obstet. Gynecol. 87 (1963) 814

[11] HUCH, A., R. HUCH, H. SCHNEIDER, J. PEABODY: Experience with transcutaneous $\mathrm{PO}_{2}\left(t c \mathrm{PO}_{2}\right)$ monitoring of mother, fetus and newborn. J. Perinat. Med. 8 (1980) 51

[12] HÖKEGÅRD, K.-H., K. KARLSSON, I. KJELLMER, K. G. ROSEN : ECG changes in the fetal lamb during asphyxia in relation to beta-adrenoceptor stimulation and blockade. Acta physiol. scand. 105 (1979) 195
[13] HÖKEGÅRD, K.-H., B.O.ERIKSSON, I. KJELLMER, R. MAGNO, K. G. ROSEN: Myocardial metabolism in relation to electrocardiographic changes and cardiovascular function during graded hypoxia in the fetal lamb. Acta Physiol. Scand. 113 (1981) 1

[14] IKENOUE, T., C. B. MARTIN JR., Y. MURATA, B. B. ETTINGER, S. L. PETER: Effect of acute hypoxemia and respiratory acidosis on the fetal heart rate in monkeys. Am. J. Obstet. Gynecol. 141 (1981) 797

[15] JOELSSON, I., M. D. BARTON, S. DANIEL, L. S. JAMES, K. ADAMSONS: A method for prolonged monitoring of physiologic functions during fetal life. Am. J. Obstet. Gynecol. 107 (1970) 445

[16] JOUBERT, D. M.: A study of prenatal growth and development in the sheep. J. Agr. Sci. 47 (1956) 382

[17] KARINIEMI, V., M. FORSS, P. LEHTOVIRTA, I. RAURAMO: Significant correlation between maternal hemodynamics and fetal heart rate variability. Am. J. Obstet. Gynec. 144 (1982) 43

[18] KARINIEMI, V., A. SIIMES, P. ÄMM ̈̈L ̈̈: Antepartal analysis of fetal heart rate variability by abdominal electrocardiography. J. Perinat. Med. 10 (1982) 114

[19] LANGER, O., E. W. W. SONNENDECKER, M. J. JACOBSON: Categorization of terminal fetal heartrate patterns in antepartum cardiotocography. Br. J. Obstet. Gynecol. 89 (1982) 179

[20] LILJA, H., K. KARLSSON, K. LINDECRANTZ, K. G. ROSEN: Computerized waveform analysis of the fetal ECG as a method to detect early asphyxia during labour. Abstract. 8th European Congress of Perinatal Medicine, Brüssel 1982

[21] MILLER, F. C., R. H. PAUL: Intrapartum fetal heart rate monitoring. In: Clin. Obstet. Gynecol. 21 (2) (1978) 561

[22] MURATA, Y., C. B. MARTIN, K. MIYAKE, M. SOCOL, M.DRUZIN: Effect of catecholamine on fetal breathing activity in rhesus monkeys. Am. J. Obstet. Gynecol. 139 (1981) 942

[23] PADBuRY, J. F., B. ROBERMAN, T. H. ODDIE, C. J. HOBEL, D. A. FISHER: Fetal catecholamine release in response to labor and delivery. Obstet. Gynecol. 60 (1982) 607

[24] PARDI, G., G. BENZI, F. COLOMBO: Fetal heart rate variability during labor. Contr. Gynec. Obstet. 3 (1977) 22 
[25] PARER, J. T., H. R. DIJKSTRA, P. P. M. VREDEBREGT, J. L. HARRIS, T. R. KRUEGER, M. L. REUSS: Increased fetal heart rate variability with acute hypoxia in chronically instrumented sheep. Europ. J. Obstet. Gynaec. reprod. Biol. 10 (1980) 393

[26] ROSEN, K. G., A. DAGBJARTSSON, B.-Å. HENRIKSSON, H. LAGERCRANTZ, I. KJELLMER: The relationship between circulating catecholamines and ST waveform in the fetal lamb electrocardiogram during hypoxia. Submitted for publication. Am.J. Obstet. Gynecol.

[27] STÅNGE, L., K. G. ROSEN, K.-H. HరKEGÅRD, K. KARLSSON, F. ROCHLITZER, I. KJELLMER, I. JOELSSON: Quantification of fetal heart rate variability in relation to oxygenation in the sheep fetus. Acta Obstet. Gynec. Scand. 56 (1977) 205

[28] WHEELER, T., E.COOKE, A.MURRILLS: Computer analysis of fetal heart rate variation during normal pregnancy. Br.J. Obstet. Gynaecol. 86 (1979) 186
[29] WILLCOURT, R. J., J. C. KING, L. INDYK, J. T. QUEENAN: The relationship of fetal heart rate patterns to the fetal transcutaneous $\mathrm{pO}_{2}$. Am. J. Obstet. Gynecol. 140 (1981) 760

[30] YEH, S.-Y., A. FORSYTHE, E. H. HON: Quantification of fetal heart beat-to-beat interval differences. Obstet. Gynecol. 41 (1973) 355

Received February 14, 1983. Revised May 26, 1983. Accepted January 23, 1984.

H. Lilja, M.D.

Division of Perinatal Physiology

Department of Physiology

University of Göteborg

Box 33031

S-400 33 Göteborg, Sweden 


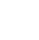

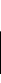

